Guidelines

\title{
Interim-Guidelines for COVID-19 Vaccination in Hematological Malignancies and Hematopoietic Stem Cell Transplant Recipients
}

\author{
Raheel Iftikhar', Uzma Zaidi²,* \\ ${ }^{1}$ Department of Clinical Hematology, Armed Forces Bone Marrow Transplant Centre, Rawalpindi, Punjab, Pakistan. \\ ${ }^{2}$ Department of Clinical Hematology, National Institute of Blood Disease \& Bone Marrow Transplantation, Karachi, Pakistan.
}

\begin{abstract}
Objective: Hematologic malignancies such as Acute Leukemias, Myelodysplastic Syndromes (MDS), Myeloproliferative Neoplasms (MPNs), Lymphomas and Multiple Myeloma (MM) can be treated with chemotherapy, Hematopoietic Stem Cell Transplant (HSCT) or Chimeric Antigen Receptor T-cell (CAR-T) therapies with either a curative intent or to prolong survival. The hematologic malignancy itself or the anti-cancer therapies can result in long-term immunodeficiency; COVID-19 infection in this population is associated with a significantly higher risk of hospitalization and death [1].

Given lack of available data on COVID-19 vaccination from Pakistan, this guidance is based on the review of safety and efficacy of FDA and CDC approved vaccines for the prevention of COVID-19 disease and recommendations of European Society for Blood and Marrow Transplant (EBMT), American Society for Transplantation and Cellular Therapies (ASTCT) and British Society of Hematology (BSH) for the use of COVID vaccination in HSCT recipients and those with hematological malignancies.
\end{abstract}

The American Society of Hematology (ASH), EBMT, ASTCT and BSH recommends the desired access to vaccines for this highly susceptible group along with care takers, family members, and domestic\& everyday contacts when vaccine supply is available.

Keywords: COVID-19 vaccination, Hematological malignancies, Hematopoietic stem cell transplant, mRNA vaccine, Acute leukemia, Chemotherapy.

\section{GUIDELINE WRITING METHODOLOGY}

PUBMED was searched systematically for all the recommendations available to date using a variety of key words. The authors prepared the initial draft, which was subsequently reviewed by senior haematologists and members of the PBMT. Comments were incorporated where appropriate.

\section{GUIDELINE QUESTIONS}

1. What Different COVID Vaccines are Available for Immunization? Which of them are FDA Approved?

Four vaccines have received FDA approval so for, Moderna, BioNTech, AstraZeneca, Johnson and Johnson. In addition, Gamaleya's Sputnik V vaccine, Chinese SinoPharm and CanSino vaccine are used in some European and Asian countries.

\section{Which Vaccines are Currently Available in Pakistan? Are they FDA Approved?}

Currently (updated $6^{\text {th }}$ April, 2021) three vaccines are available in Pakistan. Inactivated viral particle vaccine (SinoPharm) and two viral vector based vaccines (Sputnik V and CanSino). CanSino has advantage of being only single dose vaccine available in Pakistan). None of them are FDA approved.

*Address correspondence to this author at the Department of Clinical Hematology, National Institute of Blood Disease \& Bone Marrow Transplantation, Karachi, Pakistan. Email: uzaidi26@gmail.com

\section{What is the Evidence behind Use of Non-FDA Approved} Vaccines in Pakistan?

Interim results of phase III trial for BBIBP-CorV (SinoPharm) vaccine were announced on December 9, 2020 documenting $86 \%$ efficacy against COVID-19 infection [2]. CanSino $(\mathrm{Ad} 5-\mathrm{nCoV})$ is a single dose, vector-based vaccine for COVID-19 with Phase-3 clinical trials conducted in Pakistan, Mexico, Russia, Chile, and Argentina enrolling more than 4000 participants $[3,4]$.

Sputnik V (Gam-COVID-Vac) is another vector-based vaccine manufactured in Russia. The results of an interim analysis from the Moscow trial, published in February 2021 demonstrated $91.6 \%$ efficacy (95\% CI 85.6-95.2) after the second vaccination, without unusual side effects [5].

\section{Are COVID-19 Vaccines Safe and Effective in HSCT Recipients and Patients of Hematological Malignancy?}

Patients of HSCT and those receiving CAR-T cells were excluded from COVID-19 vaccine trials. Resultantly, it is unknown if the currently available COVID-19 vaccines are efficacious in patients with blood cancer and/or have undergone HSCT or CAR-T cell therapy. However, in the Pfizer-BioNTech vaccine trial, 3.9\% of enrolled participants had a malignancy and no untoward effects were observed in them [6]. Different hematological societies ASH, EBMT, ASTCT, BSH strongly recommends vaccination preferably 
with mRNA-based vaccine in this patient population.

\section{Is SARS-CoV2 Vaccine Safe in Patients with Prior SARS-CoV2 Exposure and Active COVID-19?}

Clinical trials of SARS-CoV2 vaccine included patients with previous COVID-19 infection and have documented safety in this subgroup. However, for patients with active SARS-CoV2 infection, vaccination is not recommended. For HSCT or CAR $\mathrm{T}$ cell therapy recipients COVID-19 vaccination is recommended when the symptoms completely settle.

6. Can We Use SARS-CoV2 Vaccine in Patients Receiving other Vaccines Post-Transplant or for Infection Prevention?

As per CDC recommendations, an interval of at least 14 days should be observed between mRNA SARS-CoV-2 vaccine and other vaccines [7-9].

7. Which Vaccines are approved for Patients with Hematological Malignancies and HSCT?

Till date, no clinical trial specifically enrolled immunocompromised patients for COVID-19 vaccine. However, trial data of mRNA and vector based vaccines included immunocompromised patients and stem cell transplant recipients. Based on available trial data, EBMT and ASH recommends use of mRNA vaccine (Moderna/National Institutes of Health, Pfizer/BioNTech) in HSCT recipients and patients of hematological malignancies. If not available, vector-based vaccines (AstraZeneca) can be used as per EMA, BSH recommendations.

\section{Which Vaccines to Use in HSCT Recipients and Hema-} tological Malignancies in Absence of mRNA Vaccines?

Inactivated viral vaccines have documented safety and efficacy in immunocompromised patients. For example, inactivated Flu vaccine can elicit immune responses between $15-63 \%$ of CLL patients and 7-26\% in patients on BTK inhibitor (ibrutinib) therapy. In Pakistan, mRNA vaccine are not available. SinoPharm vaccine is widely available and utilizes inactivated viral particles. Vaccines made on same technology are already used in immunocompromised population so SinoPharm vaccine appears feasible for use in HSCT recipients and hematological malignancies. On the basis of EMA, BSH approval of vaccine; Sputnik-V, CanSino can be used in HSCT recipients and patients of hematological malignancies $[5]$.

\section{Should Vaccine Administration in HSCT Recipients Prioritized?}

If there is a high risk of transmission in the surrounding, vaccination be initiated post-HSCT. The protective effect of an early intervention is currently unknown. Case should be taken with NCOC to include this population into high priority vaccination category.

\section{When should COVID-19 Vaccination be Postponed?}

Based on existing knowledge, criteria to postpone COVID-19 vaccination are:

a. Uncontrolled acute GVHD grades III - IV .

b. Use of anti-CD20 antibodies such as rituximab during the past six months.

c. Recent therapy with ATG or alemtuzumab during past 3 months.

d. Children $<12$ year of age (due to lack of vaccine data for children).

\section{Should HSCT Donors be Vaccinated?}

The CDC recommends the use of mRNA or protein subunit vaccines to vaccinate the donors and such individuals can donate unless they develop any symptoms.

\section{Should HSCT Donor be deferred after COVID Vacci- nation?}

For non-replicating vaccines (mRNA or virus vector-based), it might be reasonable to wait for 3-7 days after vaccination before proceeding for G-CSF mobilization to avoid corresponding toxicities before stem cell collection. In case if there is urgency, the transplant donation should not be delayed due to vaccination of the donor.

\section{Should Patients be tested for Antibody Titres Post Vaccination?}

CDC and American college of Rheumatology do not recommend antibody testing post vaccination. A positive antibody test may provide a false sense of protection in immunocompromised hosts, who otherwise may not be protected due to background immunocompromised state.

\section{What are Advantages and Disadvantages of Available Vaccines?}

Summarized in Table $\mathbf{1}$ are advantages and disadvantages of available vaccines. A major advantage of vector based and viral particle base vaccines (Sinopharm, Cansino, Johnson and Johnson, Sputnik-V, AstraZeneca) is storage temperature of $2-8^{\circ} \mathrm{C}$ negating need for refrigeration for storage, making them ideal candidates for resource constrained settings [10].

15.15. What are Recommendations for COVID-19 Vaccine in Specific Conditions?

\section{Blood Counts}

COVID-19 vaccination should be deferred in patients unwell with neutropenia until well, but may be considered in well patients with disease-related chronic neutropenia where 
Table 1. Advantages \&Disadvantages of Different Vaccines in Development [11].

\begin{tabular}{|c|c|c|c|}
\hline Vaccine Type & $\begin{array}{c}\text { Vaccine in Development/ } \\
\text { Approved }\end{array}$ & Advantages & Disadvantages \\
\hline Inactivated virus & $\begin{array}{l}\text { 1. SinoPharm (Inactivated whole } \\
\text { virus SARSCoV-2) } \\
\text { 2. SinoVAc(CoronaVac) }\end{array}$ & $\begin{array}{l}\text { 1. Inactivated virus with presenta- } \\
\text { tion of all antigens. } \\
\text { 2. Documented safety, efficacy - } \\
\text { e.g., quadrivalent infuenza } \\
\text { vaccine. } \\
\text { 3. Need not to stored frozen. }\end{array}$ & $\begin{array}{l}\text { 1. Mass production is difficult } \\
\text { 2. Biosecurity risk. }\end{array}$ \\
\hline Protein subunits & $\begin{array}{l}\text { Novavax (NVX-CoV2373) Vector } \\
\text { Institute (EpiVacCorona) }\end{array}$ & $\begin{array}{l}\text { 1. Can target antigens producing } \\
\text { neutralizing antibodies. } \\
\text { 2. Intact pathogen is not } \\
\text { introduced. }\end{array}$ & $\begin{array}{l}\text { 1. Post-translational modifica- } \\
\text { tions or conformation can be } \\
\text { lost. } \\
\text { 2. Humoral and cellular } \\
\text { responses can be low. } \\
\text { 3. Require adjuvants to boost. }\end{array}$ \\
\hline $\begin{array}{l}\text { Replication incompe } \\
\text { tent adenoviral vector }\end{array}$ & $\begin{array}{l}\text { 1. AstraZeneca (ChAdOx1 } \\
\text { nCoV-19; AZD1222) } \\
\text { 2. Johnson \& Johnson } \\
\text { 3. (Ad26.COV2.S) CanSino } \\
\text { Biologics (Ad5-nCoV) } \\
\text { 4. Gamaleya (Sputnik V) }\end{array}$ & $\begin{array}{l}\text { 1. Replication-defective, no new } \\
\text { viral particles. } \\
\text { 2. Mimics natural infection. } \\
\text { 3. Elicits humoral and cellular } \\
\text { immunity. }\end{array}$ & $\begin{array}{l}\text { 1. Lower efficacy if prior } \\
\text { anti-vector immunity exists. } \\
\text { 2. Concerns regarding thrombo- } \\
\text { sis. }\end{array}$ \\
\hline DNA & Inovio (INO-4800) & $\begin{array}{l}\text { 1. Mimic natural infection. } \\
\text { 2. Produces strong humoral and } \\
\text { cellular responses. } \\
\text { 3. Mass production is easy. }\end{array}$ & Delivery into cell nucleus. \\
\hline mRNA & $\begin{array}{l}\text { 1. Moderna (mRNA-1273) } \\
\text { 2. Pfzer-BioNTech (BNT162b2) }\end{array}$ & $\begin{array}{l}\text { 1. Delivery into cytoplasm. } \\
\text { 2. Produces strong humoral and } \\
\text { cellular responses. } \\
\text { 3. Avoids introducing pathogen. } \\
\text { 4. Mass production is easy. }\end{array}$ & $\begin{array}{l}\text { 1. Easily degraded. } \\
\text { 2. Needs lipid nanoparticle for } \\
\text { delivery. } \\
\text { 3. Requires freezing for storage. }\end{array}$ \\
\hline
\end{tabular}

neutrophil recovery is not expected $[12,13]$.

There is no consensus on an adequate platelet count for intramuscular injections. Still, practical suggestions include using a platelet threshold of $>20 \times 10^{9} / \mathrm{L}$, administering the vaccine after platelet transfusion if receiving regular transfusions, and to apply firm pressure at the injection site for at least 5 minutes [3]. For those with lower platelet counts, deep subcutaneous injections can be used.

\section{Allergy}

The above noted COVID-19 vaccines are contraindicated in individuals with past history of severe allergic reaction to any previous vaccines or anaphylaxis after administration of a previous dose of COVID-19 vaccine.

\section{Anti-Coagulant Therapy}

Anti-coagulation should not be a barrier for administering COVID-19 vaccination to patients on warfarin (INR monitoring not required prior to vaccination), novel oral anticoagu- lants (apixaban, dabigatran, edoxaban, rivaroxaban) or antiplatelet agents (aspirin, clopidogrel, ticagrelor). Patients on therapeutic dose low-molecular weight heparin (dalteparin, tinzaparin, enoxaparin, nadroparin) or fondaparinux may consider delaying their anti-coagulant dose on the day of vaccination until after the IM injection. For patients on any of the above, applying pressure to the injection site for 3 to 5 minutes post vaccination is recommended to reduce bruising.

\section{Immunotherapy}

a. Therapies Targeting B-cells Including Anti-CD20, CD19, CD22 Targeting Antibodies, BiTEs or CAR-T Cell Therapy

Patients receiving these agents may have a reduced immune response to vaccines till 6 months following completion.

\section{b. Checkpoint Inhibitors}

Previous studies have not signaled an increased risk of complications of COVID-19 for patients on checkpoint 
inhibitors. There have been theoretical concerns of an enhanced immune reaction, particularly with CTLA-4 inhibitors. However, given the seriousness of COVID-19 infection, vaccination is still recommended in this group even if a four-week window cannot be confirmed $[4,14]$.

\section{Timing of COVID-19 Vaccines in Relation to Therapy}

There are no known studies regarding the timing of COVID-19 vaccination in relation to therapy for blood cancer. In general, it is preferred that patients complete their one or two dose COVID-19 vaccination series ideally 14 days prior to starting immunosuppressive therapy [15].

*However, life-saving or prolonging therapy should not be delayed solely to complete vaccination.

Recommendations for timing of COVID-19 vaccination for patients with hematologic malignancies (either completed, starting or already receiving treatment) and patients who have undergone HSCT or CAR-T cell therapy in the past 6 months are described in Table 2 below. Any other timing should involve a case-by-case assessment.

Table 2. Suggested Timings of COVID-19 Vaccination in Patients with Hematologic Malignancies \& HSCT Recipients $[14,16-18]$.

\begin{tabular}{|c|c|}
\hline Therapy & Suggested Timings for COVID Vaccination \\
\hline $\begin{array}{l}\text { Cyclical chemotherapy - prior to starting (including } \\
\text { hypomethylating agents) }\end{array}$ & $\begin{array}{l}\text { 1) Ideally complete vaccination at least } 2 \text { weeks prior to starting. } \\
\text { 2) Alternatively, complete vaccination between cycles of therapy if clinically not } \\
\text { appropriate to wait to complete vaccination. }\end{array}$ \\
\hline $\begin{array}{l}\text { Cyclical chemotherapy - between cycles (including } \\
\text { hypomethylating agents) }\end{array}$ & $\begin{array}{l}\text { Give vaccine dose(s) between cycles: } \\
\text { Upon count recovery (if anticipated to recover) about } 1 \text { week prior to starting } \\
\text { subsequent cycle. } \\
\text { Note: Avoid on same day as treatment. }\end{array}$ \\
\hline $\begin{array}{l}\text { Single agent small molecule inhibitors (e.g. TKI, } \\
\text { BTK inhibitors) }\end{array}$ & No specific timing known. \\
\hline Immunomodulatory agents & Avoid on same day as treatment. \\
\hline Proteasome inhibitors (e.g. bortezomib) & Avoid on same day as treatment. \\
\hline Check point inhibitors & Avoid on same day as treatment. \\
\hline $\begin{array}{l}\text { CD19, CD20, CD22 targeted therapy (e.g. monoclo- } \\
\text { nal antibodies, CAR-T cell therapy) }\end{array}$ & $\begin{array}{l}\text { 1. COVID-19 vaccine course should be given four weeks or more before } \\
\text { rituximab. } \\
\text { 2. Four-six weeks after anti-CD20, COVID vaccine can be given, however } \\
\text { responses are weak up to } 6 \text { months post treatment. }\end{array}$ \\
\hline Other monoclonal antibodies & No specific timing. \\
\hline Systemic Corticosteroids & $\begin{array}{l}\text { Cyclical corticosteroids as part of chemotherapy regimens - ideally vaccinate on } \\
\text { days when not receiving corticosteroids Continuous corticosteroids - no specific } \\
\text { timing. }\end{array}$ \\
\hline Autologous HSCT & $\begin{array}{l}\text { Pre-HSCT: } \geq 2 \text { weeks prior to starting conditioning chemotherapy. } \\
\text { Post-HSCT: }>3 \text { months post-HSCT. }\end{array}$ \\
\hline Allogeneic HSCT & $\begin{array}{l}\text { Pre-HSCT: No need. If vaccinated, wait for at least } 2 \text { weeks before starting } \\
\text { conditioning } \\
\text { Post-HSCT: } \\
\text { Malignant Disorders:> } 3 \text { months post-HSCT } \\
\text { Benign Disorders: }>6 \text { months post HSCT (based on local centres experience of } \\
\text { adequate immune reconstitution } 6 \text { months post-transplant in benign disorders) } \\
\text { HSCT donors: No need. If vaccinated, wait for at least } 2 \text { weeks after the } 2 \text { nd dose } \\
\text { before donation of stem cells. } \\
\text { If urgency in transplant, can proceed without waiting (EBMT). }\end{array}$ \\
\hline
\end{tabular}




\begin{tabular}{|c|c|}
\hline Therapy & Suggested Timings for COVID Vaccination \\
\hline Aplastic Anemia on ATG & $\begin{array}{l}\text { Not on therapy or completed therapy with counts in acceptable range: No specific } \\
\text { timing required. } \\
\text { Post-therapy: }>3 \text { months post-initiation of cyclosporine/ATG. }\end{array}$ \\
\hline $\begin{array}{l}\text { Intravenous immunoglobulin (IVIG) - Not } \\
\text { COVID19 specific }\end{array}$ & $\begin{array}{l}\text { No specific timing. } \\
\text { Delay is not recommended for patients receiving IVIG (CDC). }\end{array}$ \\
\hline $\begin{array}{l}\text { Second dose of the COVD-19 vaccine in HSCT } \\
\text { recipients if infected with SARS-CoV-2 between } \\
\text { doses }\end{array}$ & $\begin{array}{l}\text { Can be offered second dose of vaccine once symptoms have resolved and } \\
\text { quarantined discontinued. }\end{array}$ \\
\hline $\begin{array}{l}\text { If HSCT and CAR T cell recipients received } \\
\text { therapy with SARS-CoV-2 monoclonal antibodies } \\
\text { or convalescent plasma }\end{array}$ & Delay COVID-19 vaccination for 90 days. \\
\hline Serologic testing after COVID vaccine & Not needed. \\
\hline Relatives/immediate contacts & As soon as possible. \\
\hline $\begin{array}{l}\text { Myeloproliferative neoplasms (CML, PV, MF) } \\
\text { patients on targeted therapies like JAK2 } \\
\text { inhibitors/TKI inhibitors }\end{array}$ & Should be vaccinated as soon as possible. \\
\hline
\end{tabular}

\section{Vaccination Recommendations for Specific Hematological Disorders Based on Current Evidence [15].}

\begin{tabular}{|c|c|}
\hline Disease & Recommendations \\
\hline Severe Hemophilia & Prophylactic dose of factor concentrates prior to vaccine. \\
\hline Mild bleeding disorders & Intra-muscular injection without any hemostatic treatment. \\
\hline $\begin{array}{l}\text { Patients on single agent Antiplatelets or Warfarin } \\
\text { INR }>3.0-\leq 4.0\end{array}$ & $\begin{array}{l}\text { Intra-muscular injections, risk of hematoma formation should be reduced by } \\
\text { application of firm pressure at the injection site for at least } 5 \text { minutes afterwards. }\end{array}$ \\
\hline Hemoglobinopathies & Should be vaccinated irrespective of specific timings. \\
\hline Acute Leukemias & $\begin{array}{l}\text { 1) Ideally complete vaccination at least } 2 \text { weeks prior to starting of chemotherapy. } \\
\text { 2) Alternatively, complete vaccination between cycles of therapy if clinically not } \\
\text { appropriate to wait to complete vaccination. }\end{array}$ \\
\hline Lymphoma & $\begin{array}{l}\text { Vaccination should be completed at least } 2 \text { weeks before any immunosuppressive } \\
\text { treatment is given. }\end{array}$ \\
\hline Chronic Lymphocytic Leukemia & $\begin{array}{l}\text { Vaccination should be completed at least } 2 \text { weeks before any immunosuppressive } \\
\text { treatment is given. }\end{array}$ \\
\hline Multiple Myeloma & $\begin{array}{l}\text { No specific safety or efficacy data of the COVID-19 vaccine in patients with MM } \\
\text { or related disorders including: Amyloidosis or MGUS is available. } \\
\text { Patients on cyclical corticosteroids, immunomodulatory agents, proteasome } \\
\text { inhibitor should avoid vaccination on the same day as of chemotherapy. }\end{array}$ \\
\hline MDS and MPN & All adults with any MDS subtypes should be vaccinated. \\
\hline Aplastic Anemia (AA) & All AA patients should be vaccinated. \\
\hline Immune Thrombocytopenia & $\begin{array}{l}\text { Chances of post -COVID vaccine ITP is either extremely rare or unrelated } \\
\text { coincidental event. The expected benefits of receiving a SARS-CoV-2 vaccine } \\
\text { likely outweigh this concern. }\end{array}$ \\
\hline
\end{tabular}




\section{What Side Effects are expected in Immunocompro- mised Patients?}

Mild-to-moderate side effects, like a low-grade fever or muscle aches, are normal and not a cause for alarm: they are signs that the body's immune system is responding to the vaccine. Rare cases of thrombocytopenia and neurological complications have been reported.

\section{AUTHORS' CONTRIBUTION}

Uzma Zaidi and Raheel Iftikhar equally contributed in the preparation of guideline, reviewing of evidence, correction of initial draft and finalizing the guideline.

\section{CONFLICT OF INTEREST}

Declared none.

\section{ACKNOWLEDGEMENTS}

Declared none.

\section{REFERENCES}

[1] Passamonti F, Cattaneo C, Arcaini L, et al. Clinical characteristics and risk factors associated with COVID-19 severity in patients with haematological malignancies in Italy: A retrospective, multicentre, cohort study. Lancet Haematol 2020; 7(10): e737-45.

[2] Xia S, Zhang Y, Wang Y, et al. Safety and immunogenicity of an inactivated SARS-CoV-2 vaccine, BBIBP-CorV: Arandomized, double-blind, placebo-controlled, phase 1/2 trial. Lancet Infect Dis 2021; 21(1): 39-51.

DOI: $10.1016 / \mathrm{S} 1473-3099(20) 30831-8$

[3] Pfizer Canada ULC, BioNTech Manufacturing $\mathrm{GmbH}$. Pfizer-BioNTech Covid-19,Vaccine Covid-19 mRNA Vaccine, Suspension for Intramuscular Injection. Pfizer-BioNTech COVID-19 vaccine product monograph. Product monograph including patient medication information. Kirkland, Quebec, Canada: Pfizer Canada ULC 2021; pp.1-33. Available at: https://covid-vaccine.canada.ca/info/pdf/pfizer-biontech-covid-19-vaccine-pm1-en.pdf.

[4] Product monograph including patient medication information. Cambridge, MA, USA: Moderna Therapeutics Inc. 2021; pp. 1-27.Available at: https://www.modernacovid19global.com/ca/product-monograph.pdf

[5] Jones I, Roy P. Sputnik V COVID-19 vaccine candidate appears safe and effective. Lancet 2021; 397(10275): 642-3. DOI: $10.1016 / \mathrm{S} 0140-6736(21) 00191-4$

[6] National Advisory Committee on Immunization. Recommendations on the use of COVID-19 vaccine(s). 2021; Available at: https://www.canada.ca/en/public-health/services/immuni$\begin{array}{llllllll}\mathrm{z} & \mathrm{a} & \mathrm{t} & \mathrm{i} & \mathrm{o} & \mathrm{n} & / & -\end{array}$ national-advisory-committee-on-immunization-naci/recomme ndations-use-covid-19-vaccines.html. [Accessed on: March 8, 2021].

[7] Sahin U, Muik A, Derhovanessian E, et al. COVID-19 vaccine BNT162b1 elicits human antibody and TH1 T cell responses. Nature 2020; 586(7830): 594-9.

DOI: $10.1038 / \mathrm{s} 41586-020-2814-7$

[8] CDC. Interim Clinical Considerations for Use of mRNA COVID-19 Vaccines Currently Authorized in the United States. 2021; Available at: https://www.cdc.gov/vaccines/c o vi d - 19 / d o w n lo a d s/s u m m a r y - i n t e r im-clinical-considerations.pdf. [Accessed on: August 14, 2021].

[9] Baden LR, El Sahly HM, Essink B, et al. Efficacy and Safety of the mRNA-1273 SARS-CoV-2 Vaccine. N Engl J Med 2021; 384: 403-16. DOI: 10.1056/NEJMoa2035389

[10] Oliver SE, Gargano JW, Marin M, et al. The advisory committee on immunization practices' interim recommendation for use of Pfizer-BioNTech COVID-19 Vaccine - United States, December 2020. MMWR Morb Mortal Wkly Rep 2020; 69(50): 1922-4. DOI: 10.15585/mmwr.mm6950e2

[11] Hwang JK, Zhang T, Wang AZ, Li Z. COVID-19 vaccines for patients with cancer: Benefts likely outweigh risks. J Hematol Oncol 2021; 14(1): 38. DOI: 10.1186/s13045-021-01046-w

[12] Polack FP, Thomas SJ, Kitchin N, et al. Safety and efficacy of the BNT162b2 mRNA Covid-19 Vaccine. N Engl J Med 2020; 383(27): 2603-15. DOI: 10.1056/NEJMoa2034577

[13] EBMT recommendations for COVID-19 vaccines. Version 5.0. 2021; pp. 1-13. Available at: https://www.eb$\mathrm{mt}$.org/sites/default/files/2021-02/COVID\%20vaccines \%20version \%205.02\%20-\%202021-02-21.pdf [Accessed on: February 21, 2021].

[14] UK Chemotherapy Board. Clinician Frequently Asked Questions (FAQs) and guidance on COVID-19 vaccine for patients receiving Systemic Anti-Cancer Therapy. Version 1.0 2020; [Accessed 12 January 2021].

[15] AstraZeneca Canada Inc. AstraZeneca COVID-19 vaccine product monograph. Mississauga, Ontario. 26 February 2021.

[16] Thrombosis Canada Guidance on COVID-19 Vaccines and Anticoagulation. December 22, 2020 [Accessed 19 January 2021].

[17] British Society for Haematology. COVID-19 Vaccine in patients with haematological disorders. V1 21 December 2020 [Accessed 19 January 2021].

[18] EBMT. COVID-19 vaccines. Version 2.0. 2020; Available at: https://www.ebmt.org/sites/default/files/2020-12/COVID\%20vaccines\%20version\%202.03\%20with\%20table .pdf. [Accessed on: December 21, 2020]. 